\title{
RADIOCHEMICAL SEPARATION OF STRONTIUM BY AMALGAM EXCHANGE
}

\author{
Igbal H. QuReshi† and W. WAYNe MeINKe \\ Department of Chemistry, University of Michigan, Ann Arbor, Michigan, U.S.A.
}

(Received 3 December 1962. Accepted 22 December 1962)

\begin{abstract}
Summary-The radiochemical separation of strontium by an amalgamexchange technique has been critically evaluated with a saturated aqueous solution of potassium chloride as an exchange medium. With an optimised procedure strontium yields of about $34 \%$ were obtained, although mineral acids and alkalies above $0 \cdot 1 \mathrm{M}$ decrease this yield considerably because of decomposition of the amalgam. In studies with tracers of 16 different elements, representative of the Periodic Table, this technique gave considerably better decontamination than does the fuming nitric acid procedure. The simple separation can be carried out in $8 \mathrm{~min}$ with no special equipment required, while application of the method to fall-out rain-water samples requires about $40 \mathrm{~min}$. This procedure can also be easily adapted to the preparation of a ${ }^{\circ 0} \mathrm{Y}$-free source of ${ }^{\circ 0} \mathrm{Sr}$.
\end{abstract}

TuE principle of isotopic exchange between a dilute amalgam of a metal and its ions in solution has proved to be very useful for rapid radiochemical separation procedures. Our recent studies on the separation of cadmium $^{3}$ and indium ${ }^{6}$ show that excellent decontamination can be obtained in a simple 10-min procedure. Indeed, this decontamination is often at least an order of magnitude better than that afforded by the best separation technique previously available.

Preliminary work in this laboratory ${ }^{1}$ also indicated the possibility of employing this novel technique for the rapid separation of strontium. In the present paper a critical study of this separation method has been made. Because a detailed evaluation of separations for strontium had already been made by Sunderman and Meinke, ${ }^{7}$ this study provided a good opportunity for the comparison of this new type of separation with optimum methods which are considered standard. This evaluation was particularly timely because of the great interest in radiochemical separations of strontium for fall-out analyses.

When a dilute amalgam of strontium is contacted with an aqueous solution containing radioisotopes of strontium, the radioactive strontium will selectively exchange with inactive strontium in the amalgam. The necessary condition for this exchange is that the concentration of inactive atoms of strontium in the amalgam should be much greater than that of its radioisotope in solution. The exchange can be represented as follows:

$$
\mathrm{Sr}(\mathrm{Hg})+\mathrm{Sr}^{* 2+} \rightleftharpoons \mathrm{Sr}^{*}(\mathrm{Hg})+\mathrm{Sr}^{2+}
$$

where the asterisk denotes a radioisotope of strontium. The amalgam is then removed and the radioactive strontium is recovered by shaking with $2 M$ hydrochloric acid.

† Present address: Pakistan Atomic Energy Commission, Karachi, Pakistan. 


\section{EXPERIMENTAL}

Apparatus

A 0.5-oz Boston-round bottle with polyethylene insert screw cap (Plax Corp., Bloomfield, Conn., U.S.A.) was used for agitating the amalgam during separation. It was clamped in a mechanical shaker (Wrist-Action Shaker, Model 33, Burrell Corp., Pittsburgh, Pa., U.S.A.), to which an extension arm of 12 in. was connected to give additional radial action.

The beta-radioactivity measurements were made with a Nuclear-Chicago proportional counter.

Low-level beta measurements were made in a Tracerlab CE-14 Low Background Beta Counter with a mylar window of $0.9 \mathrm{mg} / \mathrm{cm}^{2}$ and having a counting efficiency of $40 \%$ for ${ }^{00} \mathrm{Sr}$. An anticoincidence circuit was used in the system.

\section{Reagents}

Mercury: Baker and Adamson, analytical reagent grade, further purified by washing with dilute nitric acid, followed by rinsing with distilled water.

Strontium chloride: Baker Analysed Reagent.

Potassium chloride: Baker Analysed Reagent.

Sodium nitrate: Baker Analysed Reagent.

All other chemicals used in this work were also of analysed reagent grade.

All radioisotopes used as tracers have been described [Table $\mathrm{I}^{2}$ and Table $\mathrm{II}^{7}$ ].

${ }^{\circ 0} \mathrm{Y}$-free ${ }^{\circ 0} \mathrm{Sr}$ : ${ }^{\circ 0} \mathrm{Y}$ was extracted into $2 \mathrm{ml}$ of $0 \cdot 1 \mathrm{M}$ dibutyl phosphate from $2 \mathrm{ml}$ of equilibrium solution ${ }^{\circ 0} \mathrm{Sr}-{ }^{30} \mathrm{Y}$ in $0 \cdot 1 \mathrm{M}$ nitric acid. ${ }^{4}$ Pure ${ }^{\circ 0} \mathrm{Sr}$ tracer remains in the aqueous layer.

Strontium amalgam: Place $60 \mathrm{~g}$ of pure mercury in an electrolytic vessel as the cathode, and add $10 \mathrm{ml}$ of a saturated aqueous solution of strontium chloride. Electrolyse for $15 \mathrm{~min}$ at 7.5-8.0 V and 2.5-3.0 A, using a platinum anode. Strontium deposits in the mercury cathode forming the amalgam. Keep the surface of the mercury cathode constantly covered with a layer of strontium chloride crystals to prevent decomposition of amalgam by electrolyte; otherwise decomposition will greatly reduce current efficiency. Wash the amalgam with benzene and dry with air to determine its composition (about $1 \%$ ). Store the amalgam in an air-tight bottle for at least $3 \mathrm{hr}$ and wash with benzene before use. It has a pasty consistency and sticks to the sides of the containing vessel; it will keep its strength without decomposing for about 2 weeks.

\section{Amalgam-exchange procedure}

Place in a bottle $2 \mathrm{ml}$ of a saturated aqueous solution of potassium chloride, containing tracers of contaminating ions plus microgram amounts of inactive strontium, and agitate well to ensure thorough mixing. Radioactive strontium and non-radioactive interferences are used for yield determination. For practical samples make neutral to litmus paper and keep the volume below $4 \mathrm{ml}$. Add $100 \mu \mathrm{l}(\mathrm{ca} .1 .36 \mathrm{~g})$ of strontium amalgam containing $1 \%$ strontium by weight ( $c a .14 \mathrm{mg})$. Shake for $3 \mathrm{~min}$. Remove the supernate by suction and dry the amalgam with absorbent tissue paper. [Do not wash the amalgam or activity will be lost through decomposition of amalgam by water]. Transfer the amalgam to a bottle containing $2 \mathrm{ml}$ of $2 M$ hydrochloric acid and shake for $3 \mathrm{~min}$. Remove a $100-\mu \mathrm{l}$ aliquot of the aqueous layer containing separated strontium isotopes, evaporate on a counting plate and count. Total time for the separation is $8 \mathrm{~min}$.

\section{Procedure for rain-water samples}

To $500 \mathrm{ml}$ of rain-water add ca. $200 \mathrm{mg}$ of calcium carrier [as $1.2 \mathrm{~g}$ of $\mathrm{Ca}\left(\mathrm{NO}_{3}\right)_{\mathrm{g}} \cdot 4 \mathrm{H}_{2} \mathrm{O}$ ] and stir the solution to ensure thorough mixing. Precipitate the calcium as calcium carbonate with ca. $100 \mathrm{ml}$ of $5 \%$ ammonium carbonate solution. Digest the precipitate on a hot plate for $c a .5 \mathrm{~min}$ and separate by centrifugation of successive $50-\mathrm{ml}$ portions. Wash the precipitate with $5 \%$ ammonium carbonate solution, then dissolve in a minimum of $6 M$ hydrochloric acid. Adjust the $\mathrm{pH}$ of the solution to $c a .7$ by neutralising the excess acid with ammonia solution to the litmus colour change. If the volume of solution is greater than $4 \mathrm{ml}$, evaporate to $c a .4 \mathrm{ml}$. Saturate the solution with potassium chloride and perform the amalgam exchange as above. Total time for the entire separation is about $40 \mathrm{~min}$.

\section{DISCUSSION AND RESULTS}

Strontium amalgam was first prepared by reducing a saturated aqueous solution of strontium chloride with sodium. The amalgam thus prepared was not pure, however, but contained a small amount of sodium; therefore, the preparation was done electrolytically. The main difficulty with the electrolytic method lies in the fact 
that the amalgam is readily decomposed by the aqueous strontium chloride electrolyte. Unsuccessful attempts were made to minimise such decomposition by the use of different strontium salts, such as the nitrate, bromide, chloride and acetate, as well as other solvents, such as absolute alcohol. The extent of this decomposition was finally reduced when the surface of the mercury cathode was covered with a layer of strontium chloride crystals.

In order to determine an optimum separation procedure, a number of trial separations were made in which the shaking time, the concentration of the amalgam and the exchange medium, as well as the composition of the exchange medium, were varied.

The main difficulty encountered in selecting a suitable exchange medium lies in the fact that strontium amalgam is readily decomposed by aqueous solutions and acids. Saturated aqueous potassium chloride solution was used to keep such decomposition to a minimum. Typical yields for 3-min shaking times and $1 \%$ amalgams for $0.1 M$ hydrochloric acid, $0.5 M$ hydrochloric acid, $0.5 M$ sodium nitrate, $0.5 M$ potassium chloride and saturated aqueous potassium chloride were $15 \%, 8 \%$, $46 \%, 47 \%$ and $57 \%$, respectively. Absolute alcohol saturated with potassium chloride gave a $19 \%$ yield.

The exchange yield is also dependent upon the time of agitation, increasing with time and reaching a maximum at about 3-min, before beginning to decrease gradually. This is probably because of decomposition of the amalgam upon prolonged agitation.

As the amount of strontium in the amalgam was increased from $0.3 \%$ to $0.6 \%$, $1.0 \%$ and $1.7 \%$, the exchange yield was $41 \%, 53 \%, 57 \%$ and $58 \%$, respectively. Therefore, a $1 \%$ strontium amalgam was used in the standard separation procedure.

Self-absorption problems complicate the measurement of beta emitting ${ }^{90} \mathrm{Sr}$ in the amalgam so that studies were made of a number of back-extractants to strip strontium from the amalgam into an aqueous solution. It proved difficult to quantitatively strip out the strontium. A solution of $2 M$ hydrochloric acid was finally selected as the best of a number of stripping reagents, although it recovers only about three-fifths of the product in a 3-min agitation time.

The resultant optimum total procedure has been described above and gives a final yield of about $34 \%$ strontium. The entire separation procedure takes about $8 \mathrm{~min}$. To obtain this yield, however, it is necessary to follow exactly the procedure outlined above, otherwise low yields will result because of decomposition of the amalgam.

Purging the system with nitrogen does not produce any appreciable increase in this yield, but does cause precipitation of some potassium chloride from the saturated aqueous solution.

\section{Interferences}

Mineral acids, such as hydrochloric, hydrofluoric, nitric, phosphoric and sulphuric, seriously interfere with the amalgam-exchange procedure even at concentrations as low as $0.1 \mathrm{~N}$. Sodium hydroxide and ammonia solutions also interfere, but to a lesser extent. Some results of our interference studies are given in Table I. This appreciable decrease in the strontium yield is mainly because of decomposition of the amalgam. Thus, the best yield is obtained with a neutral solution. This serious 
TABle I.-EFfect of aCids AND alkalies on STRONTIUM YIELD IN INITIAL, EXChANGE STEP

\begin{tabular}{|c|c|c|}
\hline Substance & $\begin{array}{c}\text { Concentration, } \\
N\end{array}$ & $\begin{array}{c}\text { Yield of }{ }^{\circ 0} \mathrm{Sr} \text {, } \\
\end{array}$ \\
\hline $\mathrm{HCl}$ & 0.05 & 14 \\
\hline $\mathrm{HCl}$ & $0 \cdot 1$ & 11 \\
\hline $\mathrm{HCl}$ & 0.5 & 9 \\
\hline HF & $0 \cdot 1$ & 10 \\
\hline HF & 0.5 & 7 \\
\hline $\mathrm{HNO}_{3}$ & 0.1 & 7 \\
\hline $\mathrm{HNO}_{8}$ & 0.5 & 5 \\
\hline $\mathrm{H}_{2} \mathrm{SO}_{4}$ & $0 \cdot 1$ & 5 \\
\hline $\mathrm{H}_{2} \mathrm{SO}_{4}$ & 0.5 & 3 \\
\hline $\mathrm{H}_{3} \mathrm{PO}_{4}$ & 0.1 & 8 \\
\hline $\mathrm{H}_{\mathbf{g}} \mathrm{PO}_{\mathrm{a}}$ & 0.5 & 5 \\
\hline $\mathrm{NaOH}$ & $0 \cdot 1$ & 16 \\
\hline $\mathrm{NaOH}$ & 0.5 & 11 \\
\hline $\mathrm{NH}_{4} \mathrm{OH}$ & 0.1 & 18 \\
\hline $\mathrm{NH}_{4} \mathrm{OH}$ & 0.5 & 12 \\
\hline
\end{tabular}

Maximum yield in neutral solution under these conditions $=34 \%$

drawback of the method limits its scope and general applicability, although the yield is quite insensitive to various salt concentrations.

One would expect similar problems in application of the amalgam-exchange technique in separations of isotopes of calcium and barium because both calcium and barium have much the same reactive nature as that of strontium amalgam and are readily decomposed by acids.

\section{Decontamination}

Decontamination studies were made of this strontium amalgam-exchange procedure using tracers of 16 different elements representative of the Periodic Table. The results are summarised in Table II and are compared in Fig. 1 with the decontamination data of the $80 \%$ nitric acid precipitation method. ${ }^{7}$ Although the yield of strontium is low, the degree of separation obtained from a number of other elements is considerably better than the corresponding separation in the fuming nitric acid method.

In the precipitation methods for strontium, antimony is a prominent contaminant, but decontamination is improved by about a factor of 10 in the amalgam-exchange method. The tin contamination in this method is somewhat greater than for precipitation, probably because of reduction of tin by the amalgam. Selenium shows relatively low contamination. When selenium tracer was brought in contact with the amalgam, some of the selenium was precipitated. For this reason the amalgam was washed with water prior to drying with tissue paper, while with other tracers the amalgam was only dried with the paper.

In general, the decontamination values obtained by this method are not as good as those obtained with the cadmium and indium amalgam-exchange procedures.,6 This might be related to the high reducing power of the strontium amalgam for ions of many elements below strontium in the Electromotive Series. It may be possible to obtain a better decontamination for some of these impurities by scavenging with sodium amalgam. However, only a few preliminary experiments have been made on this approach. 


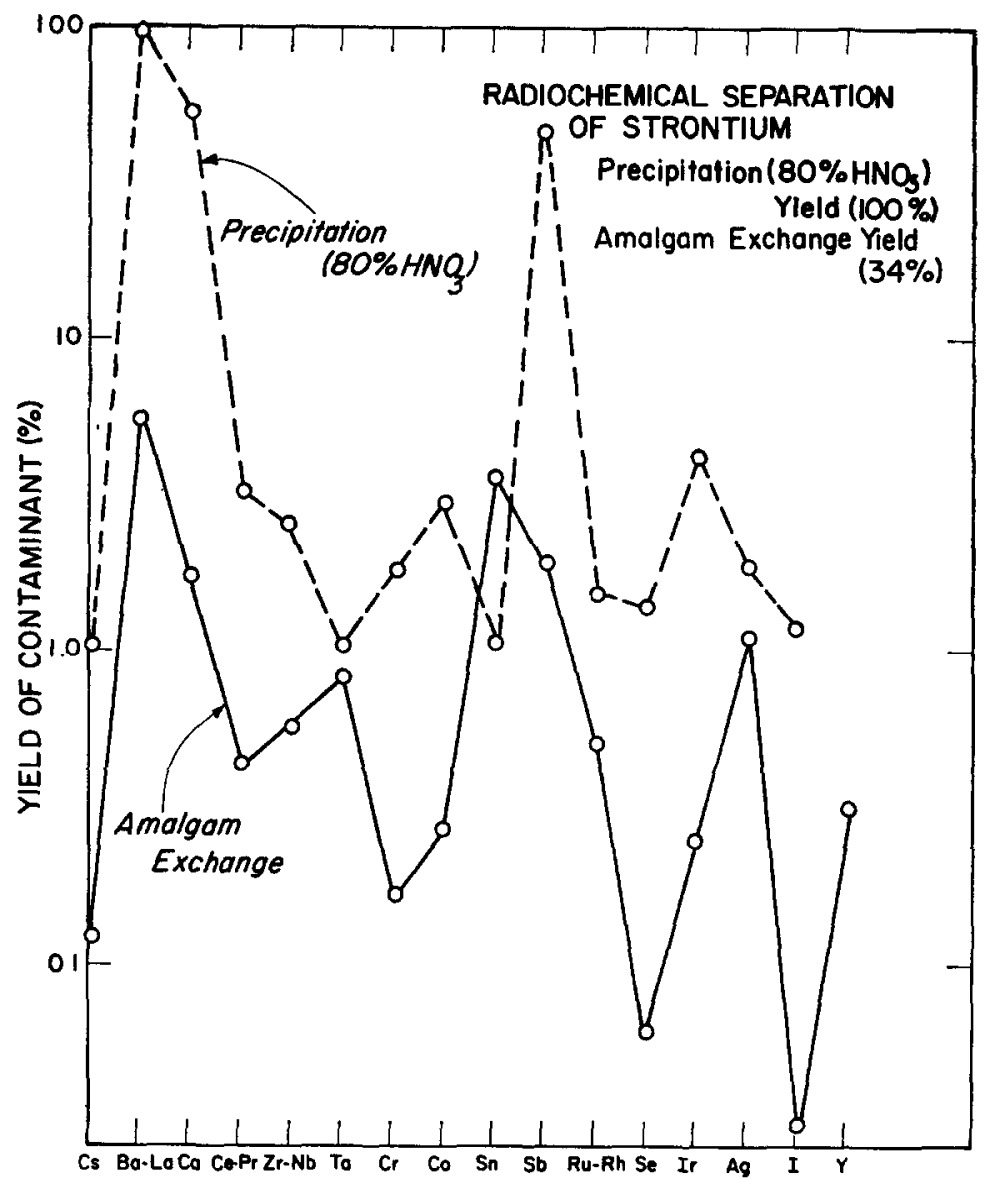

Fig. 1.-Experimental contamination for two types of strontium separations

\section{Applications}

The simple amalgam-exchange procedure can be readily used for the separation of ${ }^{90} \mathrm{Sr}$ from its daughter product ${ }^{90} \mathrm{Y}$. In another area the amalgam-exchange procedure cannot be used directly for the separation of strontium from fall-out rainwater samples because of volume limitations in the sample. An indirect method, such as that described above, whereby the strontium is precipitated on calcium carbonate carrier can be used, however. Chemical recovery of strontium was determined to be $34 \pm 2 \%$ by adding a known amount of strontium tracer $\left(10^{5}-10^{6} \mathrm{cpm}\right)$ to $500-\mathrm{ml}$ samples of distilled water and carrying out the separation in exactly the same manner as for rain-water samples.

Several rain-water samples obtained from the School of Public Health of the University of Michigan in Ann Arbor were analysed for radio-strontium by this procedure. The samples had been collected at the Willow Run Meteorological Department during the month of July, 1962. Gross activity of the samples was also determined by evaporating a total of $20 \mathrm{ml}$ in $2-\mathrm{ml}$ portions on a stainless steel planchet. All of the samples were counted through a mylar window of $0.9 \mathrm{mg} / \mathrm{cm}^{2}$ 
TABle II.-SEPARATION OF STRONTIUM AND CONTAMINANTS (AMALGAM-EXChaNGe PROCEDURE)

\begin{tabular}{|c|c|c|c|}
\hline Tracer $^{b}$ & Weight, $\mu g^{\mathrm{e}}$ & Reduction potential, $V^{d}$ & $\%$ Separated \\
\hline 181 I & C.F.; I & e & 0.03 \\
\hline${ }^{137} \mathrm{Cs}$ & C.F. & $-2 \cdot 92$ & $0 \cdot 12$ \\
\hline${ }^{140} \mathrm{Ba}-{ }^{140} \mathrm{La}$ & C.F. & $-2 \cdot 90,-2 \cdot 52$ & $5 \cdot 45$ \\
\hline${ }^{90} \mathrm{Sr}$ & C.F. & $-2 \cdot 89$ & $34 \pm 2$ \\
\hline${ }^{45} \mathrm{Ca}$ & C.F. & -2.87 & $1 \cdot \overline{7}$ \\
\hline${ }^{144} \mathrm{Ce}-{ }^{144} \mathrm{Pr}$ & C.F. & $-2 \cdot 48,-2 \cdot 47$ & 0.42 \\
\hline${ }^{91} \mathrm{Y}$ & C.F. & $-2 \cdot 37$ & 0.32 \\
\hline${ }^{95} \mathrm{Zr}-{ }^{95} \mathrm{Nb}$ & C.F. & $-1.53,-1 \cdot 1$ & 0.57 \\
\hline${ }^{182} \mathrm{Ta}$ & 970 & -0.81 & 0.83 \\
\hline${ }^{51} \mathrm{Cr}$ & $2 \cdot 5$ & -0.74 & $0 \cdot 16$ \\
\hline${ }^{60} \mathrm{Co}$ & 2 & -0.28 & 0.27 \\
\hline${ }^{113} \mathrm{Sn}$ & 270 & $-0 \cdot 14$ & $3 \cdot 7$ \\
\hline${ }^{124} \mathrm{Sb}$ & $3 \cdot 5\left(\mathrm{SbO}^{+}\right)$ & $+0 \cdot 21$ & 1.9 \\
\hline${ }^{106} \mathrm{Ru}-{ }^{106} \mathrm{Rh}$ & $6\left(\mathrm{RuCl}_{5}=\right.$ & $+0.60,+0.25$ & 0.5 \\
\hline${ }^{75} \mathrm{Se}$ & $11 \cdot 5\left(\mathrm{SeO}_{3}^{=}\right)$ & +0.74 & 0.06 \\
\hline${ }^{192} \mathrm{Ir}$ & $1\left(\mathrm{IrCl}_{6}^{=}\right)$ & +0.77 & 0.25 \\
\hline${ }^{110 \mathrm{~m}} \mathrm{Ag}$ & 16 & +0.80 & 1.08 \\
\hline
\end{tabular}

"Average of duplicate runs except for ${ }^{80} \mathrm{Sr}$, which is the average of five runs. Error is "standard deviation."

blements listed in order of their reduction potentials.

- Weight of inactive element present before separation. C.F. $=$ carrier free.

a Standard reduction potential of lowest stable oxidation state to the elemental state. Data taken from Latimer. ${ }^{5}$

${ }^{\bullet}$ Iodine in its lowest reduced state.

on the Tracerlab low-level beta counting system. The results are summarised in Tables III and IV.

Attempts were also made to apply this procedure to other environmental samples, such as milk and grass. Unfortunately, such samples require a long preparation time prior to the short amalgam-exchange step, thereby losing the time advantage of water samples.

TABLE III.-DETERMINATION OF RADIO-STRONTIUM IN RAIN-WATER SAMPLES

\begin{tabular}{|c|c|c|c|c|c|}
\hline $\begin{array}{l}\text { Sample } \\
\text { no. }\end{array}$ & $\begin{array}{l}\text { Counting } \\
\text { time, } \min \end{array}$ & Counts & $\begin{array}{l}\text { Net } \\
\text { cpm }\end{array}$ & $\begin{array}{c}\text { Amount of } \\
\text { radio-strontium, } \\
\mu c / m l\end{array}$ & $\begin{array}{c}\text { Average of } \\
\text { duplicate runs, } \\
\mu c / m l\end{array}$ \\
\hline 1 & $30^{*}$ & 528 & $16 \cdot 3$ & $\begin{array}{r}1.09 \times 10^{-7} \\
\pm 0.04 \times 10^{-7}\end{array}$ & \multirow[b]{2}{*}{$1.07 \times 10^{-7}$} \\
\hline 1 & $30^{*}$ & 510 & $15 \cdot 7$ & $\begin{array}{r}1.05 \times 10^{-2} \\
+0.04 \times 10^{-7}\end{array}$ & \\
\hline 2 & $35^{*}$ & 539 & $14 \cdot 1$ & $\begin{array}{r}0.94 \times 10^{-7} \\
\pm 0.04 \times 10^{-7}\end{array}$ & \multirow{2}{*}{$0.93 \times 10^{-7}$} \\
\hline 2 & $35^{*}$ & 529 & $13 \cdot 8$ & $\begin{array}{r}0.92 \times 10^{-7} \\
+0.03 \times 10^{-7}\end{array}$ & \\
\hline 3 & $50 \dagger$ & 525 & $9 \cdot 3$ & $\begin{array}{r}0.60 \times 10^{-7} \\
\pm 0.04 \times 10^{-7}\end{array}$ & \multirow[b]{2}{*}{$0.62 \times 10^{-7}$} \\
\hline 3 & $50 †$ & 546 & 9.7 & $\begin{array}{r}0.64 \times 10^{-7} \\
\pm 0.03 \times 10^{-7}\end{array}$ & \\
\hline
\end{tabular}

Errors are "standard deviation"

* Background $=1.3 \mathrm{cpm}$

$\dagger$ Background $=1 \cdot 2 \mathrm{cpm}$ 
TABLE IV.-DETERMINATION OF GROSS ACTIVITY IN RAIN-WATER SAMPLES

\begin{tabular}{cccccccc}
\hline $\begin{array}{c}\text { Sample } \\
\text { no. }\end{array}$ & $\begin{array}{c}\text { Counting } \\
\text { time, } \\
\text { min }\end{array}$ & Counts & cpm & $\begin{array}{c}\text { gack- } \\
\text { cpm }\end{array}$ & $\begin{array}{c}\text { Net } \\
\text { cpm }\end{array}$ & $\begin{array}{c}\text { Volume } \\
\text { of sample, } \\
m l\end{array}$ & $\begin{array}{c}\text { Gross } \\
\text { activity, } \\
\mu c / m l\end{array}$ \\
\hline 1 & 50 & 565 & $11 \cdot 3$ & $1 \cdot 2$ & $10 \cdot 1$ & 20 & $5 \cdot 7 \times 10^{-7}$ \\
2 & 50 & 510 & $10 \cdot 2$ & $1 \cdot 2$ & $9 \cdot 0$ & 20 & $5 \cdot 1 \times 10^{-7}$ \\
3 & 80 & 488 & $6 \cdot 1$ & $1 \cdot 2$ & 4.9 & 20 & $2 \cdot 75 \times 10^{-7}$ \\
\hline
\end{tabular}

Standard deviation of the counting rate is $c a .5 \%$.

The amalgam-exchange procedure for the separation of radioisotopes of strontium is rapid and relatively selective. Although the over-all yield of strontium is rather low ( $\mathrm{ca} .34 \%$ ), the improved decontamination it affords over other standard separation steps makes it worthy of consideration. Although acids and alkalies interfere markedly, salts generally have little effect; thus, rough neutralisation to a litmus colour change is usually sufficient for satisfactory results. The technique is rapid and can be easily applied to practical samples, such as rain-water. Furthermore, it eliminates the necessity for working with highly corrosive reagents.

Acknowledgements-This work was supported in part by the U.S. Atomic Energy Commission. The stay of one of us (I. Q.) was also supported by a training scholarship from the U.S. Agency for International Development. The assistance of Charles A. Pelletier and others of the University of Michigan School of Public Health in furnishing the environmental samples is gratefully acknowledged.

Zusammenfassung-Die radiochemische Abtrennung des Strontiums mittels Amalgamaustausches in gesättigter, wässriger Kaliumchloridlösung wurde kritisch untersucht. Unter optimalen Bedingungen wurde eine Strontiumausbeute von $34 \%$ erzielt. Säuren und Basen in Konzentrationen höher als $0,1 \mathrm{~m}$ erniedrigen die Ausbeute beträchtlich, da das Amalgam zersetzt wird. Studien mit Tracern von 16 verschiedenen Elementen, die einen representativen Durchschnitt des periodischen Systems darstellten, haben gezeigt, dass diese Arbeitsweise eine wesentlich bessere Decontaminierung ergab, als die Methode mit rauchender Salpetersäure. Ein Trennung kann innerhalb von 8 Minuten durchgeführt werden, wenn keine besonderen Vorkehrungen nötig sind. Regenwasser bedarf einer Zeit von etwas 40 Minuten. Die Methode kann leicht zur Gewinnung von $\mathbf{Y}^{90}$-freien $\mathbf{S r}^{90}$ adaptiert werden.

Résumé-La séparation radiochimique du strontium au moyen d'un amalgame d'échange a été étudiée systématiquement en utilisant une solution aqueuse saturée de chlorure de potassium comme milieu d'échange. Dans les meilleures conditions, on obtient environ $34 \%$ de strontium bien que les acides minéraux et les bases en concentration supérieure à 0,1 $\mathrm{M}$ abaissent considérablement le rendement par décomposition de l'amalgame. Les essais effectués avec 16 radio-traceurs différents, typiques de la classification périodique des éléments, montrent que cette technique permet unc décontamination bien meilleure que celle obtenue par le procédé à l'acide nitrique fumant. La séparation simple peut être effectuée en 8 minutes, sans appareillage spécial, alors que la méthode d'entraînement à l'eau de pluie nécessite environ 40 minutes. Ce procédé peut également être facilement adapté à la production de $\mathrm{Sr}^{80}$ purifié de $\mathrm{Y}^{80}$

\section{REFERENCES}

${ }^{1}$ J. R. DeVoe, C. K. Kim and W. W. Meinke, Talanta, 1960, 3, 298.

2 J. R. DeVoe and W. W. Meinke, Analyt. Chem., 1959, 31, 1428. 
${ }^{3}$ J. R. DeVoe, H. W. Nass and W. W. Meinke, ibid., 1961, 33, 1713.

4 D. Dyrssen, Acta Chem. Scand., 1957, 11, 1277.

${ }^{5} \mathrm{~W}$. Latimer, The Oxidation States of the Elements and Their Potentials in Aqueous Solutions. Prentice-Hall, Inc., New York, N.Y., 2nd Ed., 1952.

6 R. R. Ruch, J. R. DeVoe and W. W. Meinke, Talanta, 1962, 9, 33.

${ }^{7}$ D. N. Sunderman and W. W. Meinke, Analyt. Chem., 1957, 291578. 